\section{Protective action of priming agents on Urochloa brizantha seeds under water restriction and salinity conditions}

\author{
Thaísa Fernanda Oliveira ${ }^{1 *}(\mathbb{D})$, Heloisa Oliveira dos Santos ${ }^{1}(\mathbb{D}$, Douglas \\ Pelegrini Vaz-Tostes $^{1}{ }^{(\mathbb{D}}$, Pedro Yuri Cavasin ${ }^{1}$ (iD) , Debora Kelli Rocha ${ }^{1}$ (i) , Giovani \\ Virgílio Tirelli ${ }^{1}$
}

ABSTRACT: Analyses of germination of seeds under artificial stress conditions are tools for a better understanding of the survival and adaptation capacity of species under natural stress conditions. Therefore, the aim of this study was to evaluate the effect of priming on seed germination, on breaking of dormancy, and on the length of Urochloa brizantha seedlings under water restriction and salt stress conditions. A completely randomized experimental design was used with four replications in a $3 \times 6$ factorial arrangement consisting of 3 germination conditions (water, water restriction with PEG, and salinity with $\mathrm{NaCl}$ ) and 6 treatments [five priming solutions (distilled water, potassium nitrate, spermidine, gibberellin, and sodium nitroprusside) and a control (unprimed seeds)]. The following determinations were made: seed moisture content after priming (before drying) and after drying the seeds, germination test at seven and twenty-one days after sowing, germination speed index, viability by the tetrazolium test of the seeds remaining from the germination test, and seedling length. Priming is effective in minimizing the negative effects of water restriction and salinity. Use of sodium nitroprusside as a priming solution results in a lower percentage of dormant seeds and greater germination, vigor, and plant development.

Index terms: brachiaria, sodium nitroprusside, spermidine, water stress, salt stress.

\section{Ação protetora de condicionantes em sementes de Urochloa brizantha submetidas à restrição hídrica e salinidade}

RESUMO: A resposta germinativa de sementes submetidas à condição de estresses artificiais são ferramentas para um melhor entendimento da capacidade de sobrevivência e adaptação das espécies em condições de estresses naturais. Diante disso, o objetivo neste trabalho foi avaliar o efeito do condicionamento fisiológico na germinação de sementes, quebra de dormência e comprimento de plântulas de Urochloa brizantha sob condições de restrição hídrica e estresse salino. O delineamento utilizado foi inteiramente casualizado, com quatro repetições, em esquema fatorial $(3 \times 6)$, sendo três condições de germinação (água, restrição hídrica com PEG e salinidade com $\mathrm{NaCl}$ ) e 6 tratamentos que constituíram as cinco soluções condicionantes (água destilada, nitrato de potássio, espermidina, giberelina e nitroprussiato de sódio) mais um controle (semente não condicionada). Determinou-se: teor de água após condicionamento (antes da secagem) e após a secagem das sementes; germinação aos sete e aos vinte e um dias após a semeadura; índice de velocidade de germinação; viabilidade pelo teste de tetrazólio das sementes remanescentes do teste de germinação; e comprimento de plântulas. 0 condicionamento fisiológico é eficiente em minimizar os efeitos negativos da restrição hídrica e salinidade. Com a utilização de nitroprussiato de sódio no condicionamento ocorre menor porcentagem de sementes dormentes e maior germinação, vigor e desenvolvimento de plantas.

Termos para indexação: braquiária, nitroprussiato de sódio, espermidina, estresse hídrico, estresse salino.
Journal of Seed Science, v.43, e202143010, 2021

http://dx.doi.org/10.1590/ 2317-1545v43237830 


\section{INTRODUCTION}

The production of forage seeds, especially those of the Urochloa genus, serves a growing market and has expanded to various regions of Brazil and of the world (ABRASEM, 2018). However, more research is required, and setting up the crop does not always achieve satisfactory results (Catuchi et al., 2019; Ribeiro et al., 2019).

Quite frequently, the problem of poor pasture formation begins from not using vigorous seeds that have good performance in the stress situations to which they are exposed in the initial phases of germination (Cardoso et al., 2014; Bonome et al., 2017). Salinity and water deficit are among the main stress situations that affect germination and seedling emergence in the field, especially in arid and semi-arid regions (Gupta et al., 2014; Saberali and Moradi, 2019). Responses to water restriction and to salinity are closely related and the mechanisms overlap, suggesting that in both cases, the stress is perceived by plant cells as a water privation event (Bhanuprakash and Yogeesha, 2016).

Nevertheless, salinity from $\mathrm{NaCl}$ does not act only by restricting water absorption and causing water stress, but also causes toxicity, due to the $\mathrm{Na}^{+}$and $\mathrm{Cl}^{-}$ions. This brings about ionic imbalance in the cell cytoplasm, which may lead to formation of reactive oxygen species (ROS) that cause lipid peroxidation of the membrane, DNA damage, protein denaturation, carbohydrate oxidation, and reduction in enzymatic activity (Li et al., 2018; Liu et al., 2019).

One of the methods used to determine plant tolerance to water stress is assessment of the germination capacity of seeds under water restriction with polyethylene glycol (PEG), which is an effective technique since this inorganic compound reduces the osmotic potential of the solution and conducts controlled restriction in seed imbibition without causing toxicity (Pereira et al., 2012; Barbieri et al., 2019).

Studies related to the germination response of seeds under artificial stress conditions assist in understanding the survival and adaptation capacity of the species under the conditions of natural stresses common in agricultural and forest regions (Bhanuprakash and Yogeesha, 2016; Barbieri et al., 2019; Saberali and Moradi, 2019). In addition, techniques that aim at reducing the risks to which seeds are exposed in the field are increasingly under study. Among them is seed priming, a technique in which water is absorbed by the seed under controlled conditions. This absorption activates seed metabolism during phases I and II of imbibition, yet impedes radicle emergence (Bhanuprakash and Yogeesha, 2016; José et al., 2016).

This technique allows for a longer time for membrane repair and reorganization, making it possible for plant tissue to develop in an ordered way, which reduces risks of damage to the embryonic axis (Bonome et al., 2017; Batista et al., 2018; Pereira et al., 2018; Ribeiro et al., 2019). Thus, the aim of this study was to assess the effect of priming on seed germination, on breaking of dormancy, and on seedling length of Urochloa brizantha cv. Marandu under water restriction and salt stress conditions.

\section{MATERIAL AND METHODS}

The experiment was conducted in the Central Seed Laboratory of the Department of Agriculture of the Universidade Federal de Lavras, MG, Brazil. Urochloa brizantha cv. Marandu (brachiaria grass) seeds were used, provided by the company Sementes Mineirão Ltda., produced in the 2017/2018 crop season.

The brachiaria seeds were primed. This was performed in a BOD incubator regulated to $25^{\circ} \mathrm{C}$ (Pereira et al., 2018) without light and adapted with an air compressor that maintained the solutions aerated. The incubator was connected to hoses that released air in Erlenmeyer flasks. Forty (40) grams of seed was placed in $400 \mathrm{~mL}$ of solution in $500-\mathrm{mL}$ Erlenmeyer flasks for 42 hours. Each treatment was primed in a single Erlenmeyer flask, without replications. The priming solutions used were distilled water (water), 0.2\% potassium nitrate solution $\left(\mathrm{KNO}_{3}\right)$ (Cardoso et al., 2014; Cardoso et al., 2015), 0.5 mmol.L $\mathrm{L}^{-1}$ spermidine solution (SPER) (Hussain et al., 2015; Lopes et al., 2018), $50 \mathrm{mg} . \mathrm{L}^{-1}$ pure gibberellin solution (GB) (Batista et al., 2015; Cardoso et al., 2015), and $0.10 \mathrm{mmol} . \mathrm{L}^{-1}$ sodium nitroprusside solution (SNP) (Ataíde et al., 2015; Silva et al., 2015; Faraji et al., 2018). The seeds used as a control were not primed. 
After priming, the seeds were washed in running water, dried in an air-circulation laboratory oven for 24 hours at $25{ }^{\circ} \mathrm{C}$, and, after that, dried at $35{ }^{\circ} \mathrm{C}$ with air circulation for 72 hours. Moisture content was determined soon after priming (before drying) and after drying of the seeds, a process in which four replications of 200 seeds were removed from each treatment and dried in a laboratory oven at $105^{\circ} \mathrm{C}$ for 24 hours (Brasil, 2009).

The primed and unprimed seeds were placed under different germination conditions: control condition (distilled water), salt stress condition ( $\mathrm{NaCl}$ solution), and water restriction condition (polyethylene glycol $6000-\mathrm{PEG}$ ). The concentration used to prepare the PEG and NaCl solutions was of $-0.4 \mathrm{MPa}$ (Pereira et al., 2012), which corresponds to 178.34 g. L $^{-1}$ of PEG

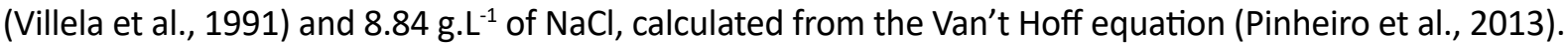

Four replications of 50 seeds were used in the germination test for all the germination conditions. The seeds were sown on two sheets of blotting paper in plastic germination boxes; the paper was moistened with water or solution volume in the amount of 2.5 times the weight of the dry paper. The seeds remained in BOD type incubation chambers with $20-35{ }^{\circ} \mathrm{C}$ alternating temperature and 8-hour photoperiod, with the first germination count made at seven days and final count at 21 days after sowing (Brasil, 2009). Together with the germination test, the modified germination speed index was determined (Maguire, 1962). A normal seedling was considered as one that had ruptured the coleoptile and whose primary leaf exhibited $50 \%$ of the aerial part surrounded by the coleoptile and $50 \%$ having already grown above it.

After the germination test was conducted, the tetrazolium test was performed on the seeds that remained (those that did not germinate and were not deteriorated or with flaccid seed tissue) (Brasil, 2009). The seeds were cut longitudinally using a tweezers and scalpel. After each seed was cut, only half was placed in $0.1 \%$ 2,3,5-triphenyl tetrazolium chloride solution in a dark container and kept in a BOD type germination chamber at the constant temperature of $40{ }^{\circ} \mathrm{C}$ for 3 hours. The seeds were evaluated considering the location and intensity of coloring of their parts, which allowed identification of viable seeds (Brasil, 2009; Dias and Alves, 2000). The viable seeds remaining from the germination test were regarded as dormant seeds and expressed in percentage. These viable seeds were not added to the sum of normal seedlings. The criterion for inclusion in germination percentage was only the percentage of normal seedlings.

Four replications of 25 seeds were used for analysis of seedling images. The seeds were sown on two sheets of germination paper and one more sheet was overlaid; the rolled seeds/paper were moistened with water or solution in the amount of 2.5 times the weight of the dry paper. They remained in BOD type chambers with 20-35 ${ }^{\circ} \mathrm{C}$ alternating temperature and 8-hour photoperiod. The rolls were placed in plastic bags to prevent moisture loss. Seedling images were obtained at 7 days after setting up the test, equivalent to the period of first germination count (Brasil, 2009).

The GroundEye ${ }^{\circledR}$ system, version $\mathrm{S} 800$, was used to capture the images. It is composed of an image capture module with an acrylic tray, a high-resolution camera, and integrated software for evaluation. The seedlings were removed from the paper and inserted in the tray of the capture module to obtain images. In the analysis configuration step, the CIELab lightness index from 0 to 100 was used for background color calibration - dimension "a" from - 17.5 to 42.5 and dimension "b" from 57.0 to -28.9. After calibration of background color, the images were analyzed and values of root length and shoot length were extracted.

A completely randomized experimental design was used, with four replications, in a $3 \times 6$ factorial arrangement, consisting of three germination conditions and six treatments, comprised of the five priming solutions plus a control (unprimed seed). Analysis of variance was performed on the mean values and, when significant, Tukey's test was applied at $5 \%$ probability.

\section{RESULTS AND DISCUSSION}

The primed seeds took up a greater amount of water when primed with sodium nitroprusside (SNP), followed by those that were primed with potassium nitrate $\left(\mathrm{KNO}_{3}\right)$ and spermidine (SPER) (Figure 1). 


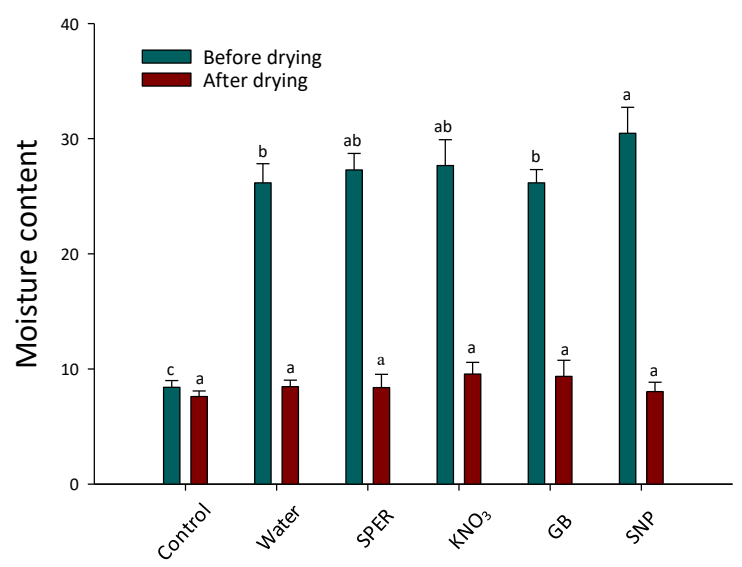

Mean values before drying and after drying followed by the same letter do not differ from each other by Tukey's test at $5 \%$ probability of error.

Figure 1. Moisture content of Urochloa brizantha seeds before and after drying without priming (Control) and under priming in solutions of water (Water), spermidine (SPER), potassium nitrate $\left(\mathrm{KNO}_{3}\right)$, gibberellin (GB), and sodium nitroprusside (SNP).

Water sufficient for initial physiological processes to occur must be absorbed in a balanced way up to equilibrium between the osmotic potential of the solution and of the seeds (Almeida et al., 2016). Hydration is important to initiate seed metabolism, which is reduced under low moisture content (Batista et al., 2016).

Batista et al. (2016) evaluated the carbohydrate content of Urochloa brizantha and found that the hydration period markedly provided a larger amount of free sugars, which would be used as energy sources during the germination process. The authors explain this by the longer time available for hydrolysis of the seed reserve tissue provided by priming.

After drying, all the treatments returned to the moisture content near that of the seeds that were not primed (Figure 1). At the end of priming, it is possible to dry the seeds until they reach the moisture content they had before the process, without losing the activation of the metabolism acquired by imbibition, which allows them to be stored for a certain time up to sowing (Wojtyla et al., 2016).

Under water restriction and salt stress, the cultivar Marandu obtained the highest percentage of germination when the seeds were primed with SPER and SNP. For water restriction with PEG, the SNP led to the highest germination percentage among all the priming solutions (Figure 2A). In relation to the unprimed seeds (control), lower germination was found under salt stress than under water restriction (Figure $2 \mathrm{~A}$ ).

Various authors have found that the positive effects of the SPER are associated with maintenance of membrane integrity, regulation of gene expression, breaking of dormancy, and seed germination, flower and fruit development, and senescence (Gupta et al., 2014; Lopes et al., 2018; Yalamalle et al., 2019). In addition, the SPER also plays a crucial role in tolerance to abiotic stresses (Yalamalle et al., 2019).

In addition to SPER, exogenous application of SNP, a nitric oxide donor, has also played important roles in tolerance to stress situations (Kaiser et al., 2016; Pires et al., 2016; Silva et al., 2019). For Senna macranthera, SNP favored seed germination under salt stress at osmotic potentials of -0.4 and $-0.5 \mathrm{MPa}$ of $\mathrm{NaCl}$ at a concentration of $100 \mu \mathrm{M}$ of SNP (Silva et al., 2019). Studies with Brassica sp. have shown that salt stress affects seed physiological quality and vigor, but that the application of SNP reverses the stress caused by salinity (Kaiser et al., 2016).

The role of nitric oxide (NO) and of other compounds containing nitrogen, such as nitrate, in breaking seed dormancy and in stimulating germination (Zanotti et al., 2013) was reported in various species. Nagel et al. (2019) studied the action of nitric oxide in breaking dormancy in barley seeds. In Arabidopsis seeds, nitric oxide reduced the ABA levels during imbibition by positive regulation of the ABACYP707A2 catabolism gene (Matakiadis et al., 2009). There are similar reports in lettuce (Beligni and Lamattina, 2000) and Paulonia tomentosa (Giba et al., 1998). 

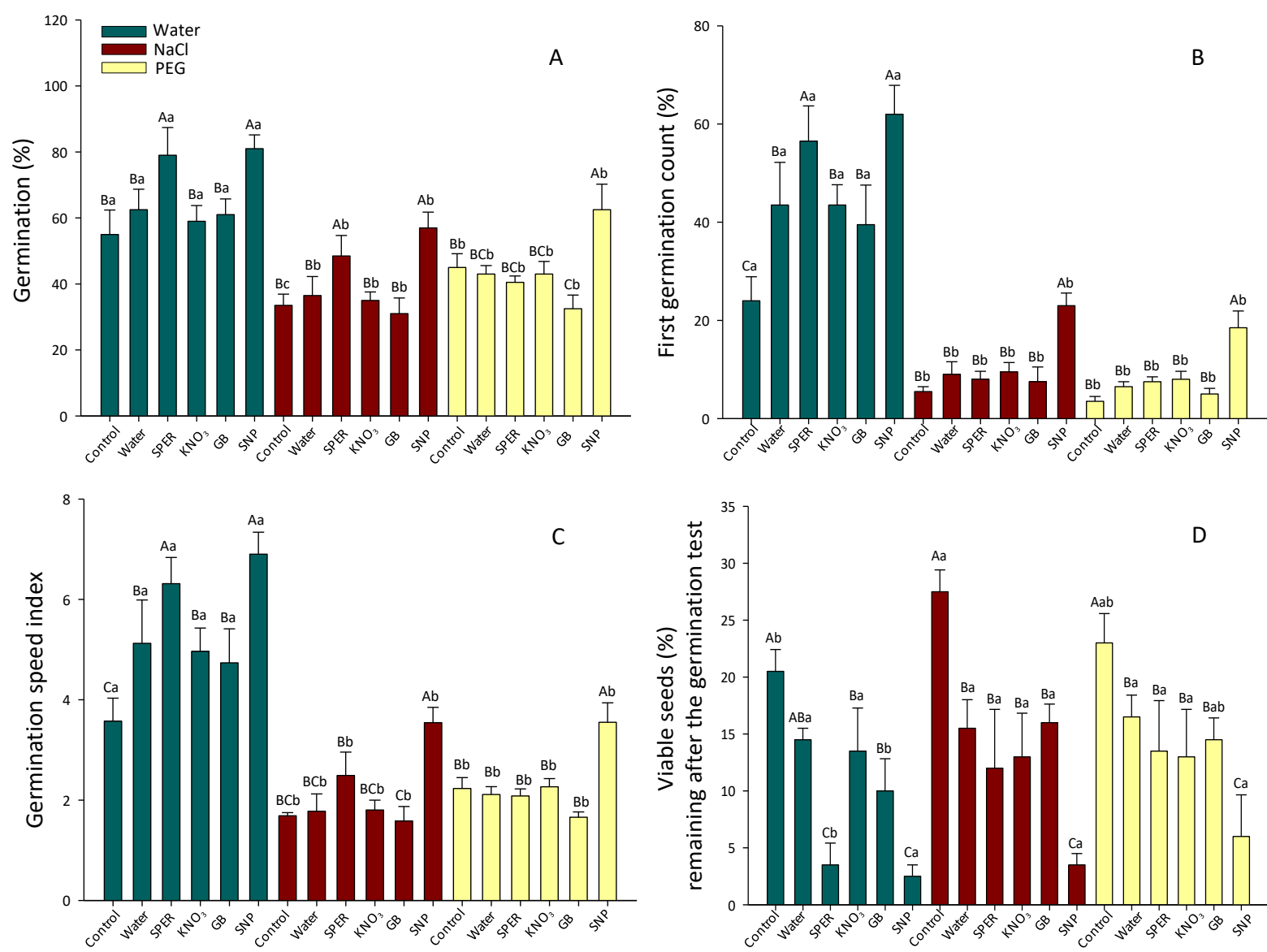

Mean values followed by the same uppercase letter among priming solutions (within each condition) and lowercase letter among conditions for germination do not differ from each other by Tukey's test at $5 \%$ probability.

Figure 2. Germination (A), First germination count (B), Germination speed index (C), and Viable seeds remaining after the germination test (D) of Urochloa brizantha seeds germinated in water (Water), under salt stress ( $\mathrm{NaCl})$, and under water restriction (PEG) without being primed (Control) and under priming in solutions of water (Water), spermidine (SPER), potassium nitrate (KNO3), gibberellin (GB), and sodium nitroprusside (SNP).

Priming led to a significant increase in first germination count compared to the control under the condition of germination in water (Figure 2B). The SNP priming agent led to the highest values of all the treatments when seeds were placed to germinate under salt stress and water restriction conditions. There was no difference for first germination count in assessment of each priming agent between the salt stress condition and water restriction condition.

Results similar to those of first germination count were observed for the germination speed index; the SNP and SPER priming agents had the highest index for the condition of germination in water (Figure 2C). Under stress conditions, SNP resulted in a germination speed index higher than the indices in the other priming solutions and the control. The stress conditions reduced the germination speed index in comparison with water, regardless of whether the seed were primed or not.

One of the factors responsible for reduction in germination may have been the excess of $\mathrm{Na}+$ and $\mathrm{Cl}$ - ions, which cause toxicity and can lead to oxidative damage in various cellular components, such as proteins, lipids and DNA, disrupting vital cell functions of plants (Gupta et al., 2014). Another factor may have been the excess of soluble salts, resulting in lower water potential, that is, seed water absorption capacity is reduced (Kaiser et al., 2016; Silva et al., 2019).

Priming reduces germination time and makes the germination process more uniform, and thus reduces the effects of the environmental variables, which allows germination under different temperature, light, soil, and water availability conditions. This then allows acceleration in shoot and root growth (Bhanuprakash and Yogeesha, 2016; Ribeiro et al., 2019). 
Under the condition of germination in water, the percentages of viable seeds remaining after the germination test were lower in the treatments primed with SPER and SNP (Figure 2D). For the salt stress and water restriction conditions, the treatments primed with SNP exhibited lower numbers of viable seeds remaining. This suggests that SPER and SNP act in breaking the dormancy of this cultivar in optimal situations; however, SNP acts in breaking dormancy not only in optimal situations but also under stress situations.

Nitric oxide (NO) was proposed as responsible for interference of ethylene and of ABA in the seed. In fact, convergent evidence indicates that $\mathrm{NO}$ is rapidly produced after seed imbibition and promotes germination, inducing expression of the ABA 8'-hydroxylase CYP707A2 gene and stimulating ethylene production (Arc et al., 2013; Bethke et al., 2018). A series of independent studies have revealed that the NO blocks the ABA signaling network in various steps, ensuring the control of germination (Krasuska et al., 2016; Graeber et al., 2012; Signorelli and Considine, 2018).

However, studies show that NO-releasing substances stimulate the germination of seeds under accelerated aging (Kaiser et al., 2016). Such substances act on the permeability of the membrane, preventing or reversing the damage caused by the abiotic stress conditions, which reduce seed vigor (Pereira et al., 2010). Considering that the salt stress and water restriction process involves changes in osmotic potential and stress on the cell membrane, it is possible that the nitric oxide-releasing agents favor the germination process under salt stress.

A smaller number of viable seeds remaining after the germination test was observed for seeds under priming compared to the control (Figure 2D). Studies showed that priming of Urochloa sp. seeds led to a lower percentage of dormant seeds and a higher percentage of germination and of seedling emergence in a shorter time (Bonome et al., 2017; Batista et al., 2018; Pereira et al., 2018; Ribeiro et al., 2019).

According to Delledonne et al. (1998), nitric oxide acts in breaking dormancy by increasing the influx of $\mathrm{Ca}^{2+}$ in the cytoplasm, which can activate the transcription of specific genes, for example TCH genes, which codify calmodulin (TCH1), and enzymes involved in synthesis and/or modification of the cell wall, which facilitates the process of cell expansion necessary for germination.

For the shoot length variable, there was no difference for the control under the conditions of growth in water, under salt stress, and under water restriction (Figure 3A). Comparing the control with the primed seeds, shoot length was less for the seeds that were primed with water than those under SNP, GB, and SPER priming. For the shoot length variable under the salt stress and water restriction conditions, the control was only inferior to the SNP.

A greater reduction in root length was observed in the seedlings in salt solution than under water restriction (Figure 3B). In growth in water and salt solution, only priming with the SNP agent led to greater root length than root length in the control. In general, the growth of this forage plant was more sensitive to salt stress than to water restriction (Figure 3 ).

In response to salt stress, the production of reactive oxygen species (ROS), such as singlet oxygen, superoxide, hydroxyl radical, and hydrogen peroxide, is enhanced (Gupta et al., 2014; Du et al., 2015; Kaiser et al., 2016; Silva et al., 2019). The formation of ROSs induced by salinity can lead to oxidative damage in various cell components, such as proteins, lipids, and DNA, interrupting vital cell functions of the plants (Gupta et al., 2014; Liang et al., 2018; Liu et al., 2019). In addition, the high concentration of $\mathrm{Na}^{+}$inhibits capture of $\mathrm{K}^{+}$ions, an element essential for growth, which results in lower yield and can even lead to plant death (Gupta et al., 2014; Liang et al., 2018).

In seedlings coming from Brassica oleracea L. seeds under salinity (-0.6 MPa), Kaiser et al. (2016) found reduction from $4.14 \mathrm{~cm}$ to $1.74 \mathrm{~cm}$ in radicle length. The authors explain that abnormal development of the seedlings caused by salinity might be associated with the action of the salts in bringing about water deficit due to the high osmotic potential of the solution; moreover, the ions may have a toxic effect, which can culminate in metabolic and physiological damage (Kaiser et al., 2016). Du et al. (2015) observed that salinity ( $200 \mathrm{mM}$ of $\mathrm{NaCl}$ ) resulted in high levels of toxic substances, such as malondialdehyde (MDA) and hydrogen peroxide $\left(\mathrm{H}_{2} \mathrm{O}_{2}\right)$, in Spinacia oleracea plants.

The increase in salinity brings about changes in plant capacity in taking up, transporting, and using the ions necessary for plant development and reduces the activity of enzymes responsible for respiration and photosynthesis (Gupta et al., 2014; Du et al., 2015; Silva et al., 2019). Thus, obtaining energy for development and differentiation of cells in plant 
tissue is restricted (Kaiser et al., 2016; Barbieri et al., 2019; Silva et al., 2019). Consequently, knowing how forage plant seeds respond under these conditions is important, especially because of the strong expansion of this crop in various regions of Brazil and around the world, not only for raising livestock but also for intercropping and in providing straw cover in the no-till system (ABIEC, 2019; ABRASEM, 2018).
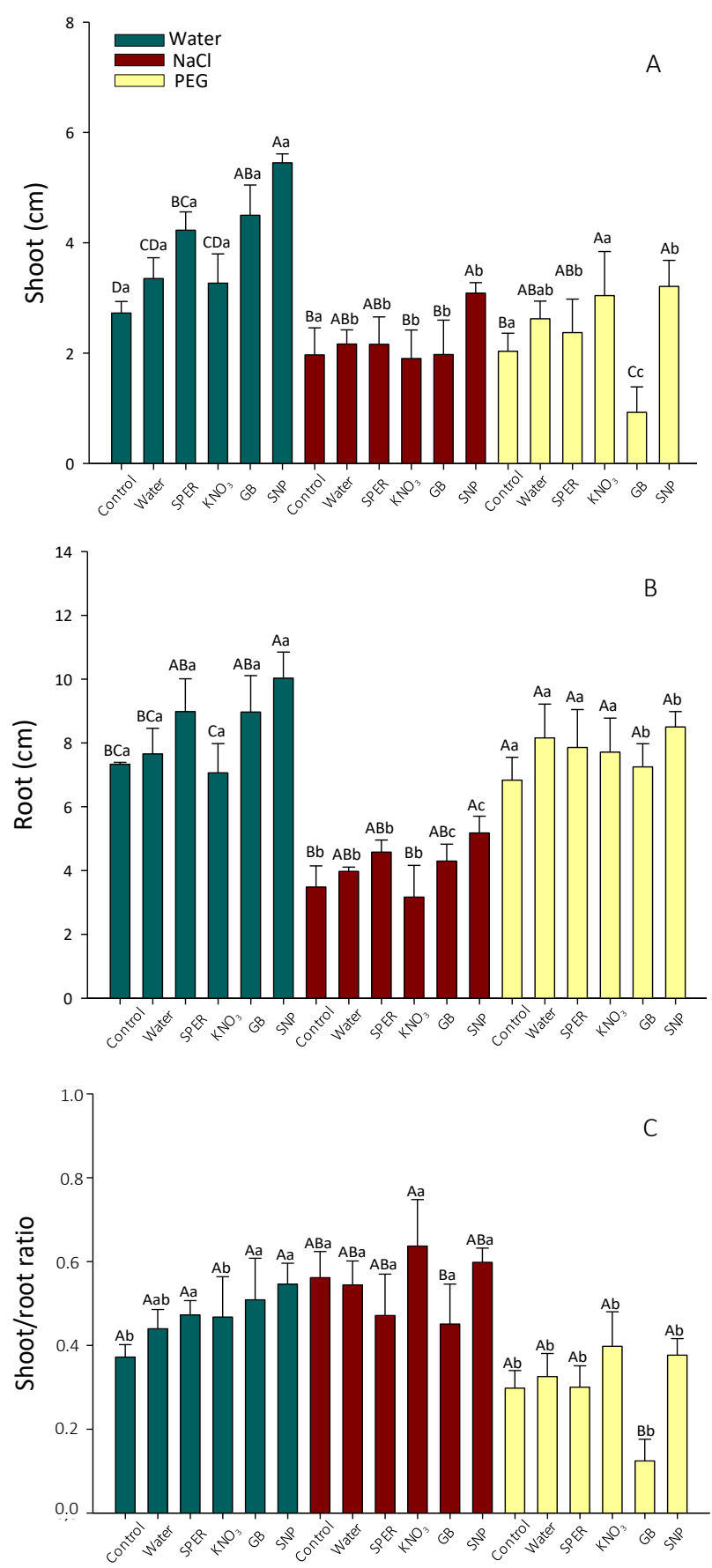

Mean values followed by the same uppercase letter among priming solutions (within each condition) and lowercase letter among conditions for germination do not differ from each other by Tukey's test at $5 \%$ probability.

Figure 3. Length $(\mathrm{cm})$ of shoots $(A)$, length of roots $(B)$, and ratio between them $(C)$ obtained by analysis of images of Urochloa brizantha seedlings at 7 days of germination in water under salt stress $(\mathrm{NaCl})$ and under water restriction (PEG) without priming (Control) and under priming in solutions of water (Water), spermidine (SPER), potassium nitrate $\left(\mathrm{KNO}_{3}\right)$, gibberellin $(\mathrm{GB})$, and sodium nitroprusside (SNP). 


\section{CONCLUSIONS}

Priming is effective in minimizing the negative effects of water restriction and salinity.

A lower percentage of dormant seeds and greater germination, vigor, and plant development occur with the use of sodium nitroprusside in seed priming.

\section{ACKNOWLEDGMENTS}

The authors thank the research promotional agencies Coordenação de Aperfeiçoamento de Pessoal de Nível Superior (CAPES - Brasil), Fundação de Amparo à Pesquisa de Minas Gerais (FAPEMIG - Brasil), and the Conselho Nacional de Desenvolvimento Científico e Tecnológico (CNPq).

\section{REFERENCES}

ABIEC. Associação Brasileira das Indústrias Exportadoras de Carnes. Perfil da pecuária no Brasil. Relatório Anual 2019. Available on: http://abiec.com.br/publicacoes/beef-report-2019/ Accessed on: January, 2021.

ABRASEM. Associação Brasileira de Sementes e Mudas. Anuário 2018. Available on: http://www.abrasem.com.br/wp-content/ uploads/2020/06/Arte_Anuario2018_COMPLETO_WEB.pdf Accessed on: January, 2020.

ALMEIDA, A.S.; BORTOLOTTI, M.; MEDEIROS, L.R.; MENEGHELLO, G.E.; KONZEN, L.H.; TUNES, L.M. Protrusão da radícula e métodos para superação de dormência de sementes de trigo. Revista de Ciências Agroveterinárias, v.15, n.3, p.271-276, 2016. https://doi. org/10.5965/223811711532016271

ARC, E.; SECHET, J.; CORBINEAU, F.; RAJJOU, L.; MARION-POLL, A. ABA crosstalk with ethylene and nitric oxide in seed dormancy and germination. Frontiers in Plant Science, v.4, p.63, 2013. https://doi.org/10.3389/fpls.2013.00063

ATAÍDE, G.M.; BORGES, E.E.; FLORES, A.V.; CASTRO, R.V. Óxido nítrico na germinação de sementes de baixo vigor de Dalbergia nigra. Revista de Ciências Agrárias, v.38, n.3, p.438-444, 2015. http://www.scielo.mec.pt/scielo.php?script=sci_arttext\&pid=S0871$018 \times 2015000300019$

BARBIERI, G.F.; STEFANELLO, R.; MENEGAES, J.F.; MUNARETO, J.D.; NUNES, U.R. Seed germination and initial growth of quinoa seedlings under water and salt stress. Journal of Agricultural Science, v.11, n.15, p.153-161, 2019. https://doi.org/10.5539/jas. v11n15p153

BATISTA, T.B.; CARDOSO, E.D.; BINOTTI, F.F.S.; SÁ, M.E.; HAGA, K.I. Nutrientes e giberelina no condicionamento fisiológico sob a qualidade de sementes de braquiária. Revista de Agricultura Neotropical, v.2, n.1, p.10-16, 2015. https://periodicosonline.uems. br/index.php/agrineo/article/view/253

BATISTA, T.B.; BINOTTI, E.D.C.; BINOTTI, F.F.S.; SÁ, M.E.D.; SILVA, T.A.D. Priming of brachiaria seeds with different sugar sources and concentrations. Revista Caatinga, v.31, n.4, p.843-849, 2018. https://doi.org/10.1590/1983-21252018v31n406rc

BATISTA, T.B.; BINOTTI, F.F.S.; CARDOSO, E.D.; COSTA, E.; NASCIMENTO, D.M.D. Appropriate hydration period and chemical agent improve priming in brachiaria seeds. Pesquisa Agropecuária Tropical, v.46, n.3, p.350-356, 2016. https://doi.org/10.1590/1983$40632016 v 4638422$

BELIGNI M.V.; LAMATTINA, L. Nitric oxide stimulates seed germination and de-etiolation, and inhibits hypocotyl elongation, three light-inducible responses in plants. Planta, v.210, n.2, p.215-221, 2000. https://doi.org/10.1007/PL00008128

BETHKE, P.C.; LIBOUREL, I.G.; JONES, R.L. Nitric oxide in seed dormancy and germination. Annual Plant Reviews Online, p.153-175, 2018. https://onlinelibrary.wiley.com/doi/abs/10.1002/9780470988848\#page=171

BHANUPRAKASH, K.; YOGEESHA, H. S. Seed priming for abiotic stress tolerance: an overview. Abiotic Stress Physiology of Horticultural Crops, v.27, p.103-117, 2016. https://link.springer.com/chapter/10.1007/978-81-322-2725-0_6

BONOME, L.D.S.; DOUSSEAU, S.; GUIMARÃES, R.; OLIVEIRA, J. Osmoconditioning of Urochloa brizantha seeds to reduce pelleting negative effects. Brazilian Journal of Agriculture, v.92, n.2, p.87-100, 2017. http://biblioteca.incaper.es.gov.br/digital/handle/item/2819 
BRASIL. Ministério da Agricultura, Pecuária e Abastecimento. Regras para análise de sementes. Ministério da Agricultura, Pecuária e Abastecimento. Secretaria de Defesa Agropecuária. Brasília: MAPA/ACS, 2009. 399p. https://www.gov.br/agricultura/pt-br/ assuntos/insumos-agropecuarios/arquivos-publicacoes-insumos/2946_regras_analise_sementes.pdf

CARDOSO, E.D.; SÁ, M.E.; HAGA, K.I.; BINOTTI, F.F.S.; COSTA, E. Qualidade fisiológica e composição química de sementes de Brachiaria brizantha em função do condicionamento osmótico. Journal of Neotropical Agriculture, v.2, n.2, p.42-48, 2015. https:// periodicosonline.uems.br/index.php/agrineo/article/view/264

CARDOSO, E.D.; SÁ, M.E.; HAGA, K.I.; BINOTTI, F.F.S.; NOGUEIRA, D.C.; VALÉRIO- FILHO, W.V. Desempenho fisiológico e superação de dormência em sementes de Brachiaria brizantha submetidas a tratamento químico e envelhecimento artificial. Semina: Ciências Agrárias, v.35, n.1, p.21-37, 2014. https://www.redalyc.org/articulo.oa?id=445744139002

CATUCHI, T.A.; SORATTO, R.P.; FRANCISQUINI-JÚNIOR, A.; GUIDORIZZI, F.V.C.; TIRITAN, C.S. Manejo do nitrogênio em gramíneas forrageiras quanto à nutrição, produção de sementes e nutrientes na palhada residual. Pesquisa Agropecuária Brasileira, v.54, e00114, 2019. https://doi.org/10.1590/s1678-3921.pab2019.v54.00114

DELLEDONNE, M.; XIA, Y.; DIXON, R.A.; LAMB, C. Nitric oxide functions as a signal in plant disease resistance. Nature, v.394, n.6693, p.585-588, 1998. https://www.nature.com/articles/29087/

DIAS, M.C.L.L.; ALVES, S.J. Teste de tetrazólio em sementes de Panicum maximum e Brachiaria brizantha. Londrina: IAPAR, 2000. 11p.

DU, S.T.; LIU, Y.; ZHANG, P.; LIU, H.J.; ZHANG, X.Q.; ZHANG, R.R. Atmospheric application of trace amounts of nitric oxide enhances tolerance to salt stress and improves nutritional quality in spinach (Spinacia oleracea L.). Food Chemistry, v.173, p.905-911, 2015. https://doi.org/10.1016/j.foodchem.2014.10.115

FARAJI, J.; SEPEHRI, A.; SALCEDO-REYES, J.C. Titanium dioxide nanoparticles and sodium nitroprusside alleviate the adverse effects of cadmium stress on germination and seedling growth of wheat (Triticum aestivum L.). Universitas Scientiarum, v.23, n.1, p.61-87, 2018. http://dx.doi.org/10.11144/javeriana.sc23-1.tdna

GIBA, Z.; GRUBISIC, D.; TODOROVIC, S.; SAJC, L.; STOJAKOVIC, D.; KONJEVIC, T. Efeito de compostos liberadores de óxido nítrico na germinação controlada por fitocromo de sementes de árvores Imperatriz. Regulamento de Crescimento de Plantas, v.26, n.3, p.175-181, 1998. https://doi.org/10.1023/A:1006131215297

GRAEBER, K.; NAKABAYASHI, K.; MIATTON, E.; LEUBNER-METZGER, G.; SOPPE, W.J.J. Mecanismos moleculares de dormência de sementes. Plant, Cell Environment, v.35, n.10, p.1769-1786, 2012. https://doi.org/10.1111/j.1365-3040.2012.02542.x

GUPTA, B.; HUANG, B. Mechanism of salinity tolerance in plants: physiological, biochemical, and molecular characterization. International Journal of Genomics, v.2014, p.1-18, 2014. https://doi.org/10.1155/2014/701596

HUSSAIN, S.; ZHENG, M.; KHAN, F.; KHALIQ, A.; FAHAD, S.; PENG, S.; HUANG, J.; CUI, K.; NIE, L. Benefits of rice seed priming are offset permanently by prolonged storage and the storage conditions. Scientific Reports, v.5, n.1, p.1-12, 2015. https://www.nature. com/articles/srep08101

JOSÉ, A.C.; SILVA, N.C.N.; FARIA, J.M.R.; PEREIRA, W.V.S. Influence of priming on Eucalyptus spp. seeds' tolerance to salt stress. Journal of Seed Science, v.38, n.4, p.329-334, 2016. https://doi.org/10.1590/2317-1545v38n4165060

KAISER, I.S.; MACHADO, L.C.; LOPES, J.C.; MENGARDA, L.H.G. Efeito de liberadores de óxido nítrico na qualidade fisiológica de sementes de repolho sob salinidade. Revista Ceres, v.63, n.1, p.39-45, 2016. https://www.redalyc.org/articulo.oa?id=305244108006

KRASUSKA, U.; CIACKA, K.; ORZECHOWSKI, S.; FETTKE, J.; BOGATEK, R.; GNIAZDOWSKA, A. Modification of the endogenous NO level influences apple embryos dormancy by alterations of nitrated and biotinylated protein patterns. Planta, v.244, n.4, p.877-891, 2016. https://doi.org/10.1007/s00425-016-2553-z

LI, Z.; GAO, Y.; ZHANG, Y.; LIN, C.; GONG, D.; GUAN, Y.; HU, J. Reactive oxygen species and gibberellin acid mutual induction to regulate tobacco seed germination. Frontiers in Plant Science, v.9, n.1279, 2018. https://doi.org/10.3389/fpls.2018.01279

LIANG, W.; MA, X.; WAN, P.; LIU, L. Plant salt-tolerance mechanism: a review. Biochemical and Biophysical Research Communications, v.495, n.1, p.286-291, 2018. https://doi.org/10.1016/j.bbrc.2017.11.043

LIU, B.; SOUNDARARAJAN, P.; MANIVANNAN, A. Mechanisms of silicon-mediated amelioration of salt stress in plants. Plants, v.8, n.9, p.307, 2019. https://doi.org/10.3390/plants8090307 
LOPES, C.A.; CARVALHO, M.L.M.; SOUZA, A.C.D.; OLIVEIRA, J.A.; ANDRADE, D.B.D. Cryopreservation of primed tobacco seeds. Journal of Seed Science, v.40, n.4, 2018. https://doi.org/10.1590/2317-1545v40n4207216

MAGUIRE, J. D. Speed of germination - aid in selection and evaluation for seedling emergence and vigor. Crop Science, v.2, n.2, p.176-177, 1962. https://doi.org/10.2135/cropsci1962.0011183X000200020033x

MATAKIADIS, T.; ALBORESI, A.; JIKUMARU, Y.; TATEMATSU, K.; PICHON, O.; RENOU, J.P.; KAMIYA, Y.; NAMBARA, E.; TRUONG, H.N. The Arabidopsis abscisic acid catabolic gene cyp707a2 plays a key role in nitrate control of seed dormancy. Plant Physiology, v.149, n.2, p.949-960, 2009. DOI: https://doi.org/10.1104/pp.108.126938

NAGEL, M.; ALQUDAH, A.M.; BAILLY, M.; RAJJOU, L.; PISTRICK, S.; MATZIG, G.; BÖRNER, A.; KRANNER, I. Novel loci and a role for nitric oxide for seed dormancy and preharvest sprouting in barley. Plant, Cell and Environment, v.42, n.4, p.1318-1327, 2019. https://doi.org/10.1111/pce.13483

PEREIRA, B.L.C.; BORGES, E.E.L.; OLIVEIRA, A.C.; LEITE, H.G.; GONÇALVES, J.F.C. Influence of nitric oxide on the germination of seeds of Plathymenia reticulata benth with low vigor. Scientia Forestalis/Forest Sciences, v.88, p.629-636, 2010. https://repositorio.inpa. gov.br/handle/1/16245

PEREIRA, M.R.R.; MARTINS, C.C.; SOUZA, G.S.F.; MARTINS, D. Influência do estresse hídrico e salino na germinação de Urochloa decumbens e Urochloa ruziziensis. Bioscience Journal, v.28, n.4, 2012. http://www.seer.ufu.br/index.php/biosciencejournal/article/ view/13447

PEREIRA, S.R.; LIMA, A.D.S.; CONTREIRAS-RODRIGUES, A.D.A.; OLIVEIRA, D.R.; LAURA, V.A. Priming of Urochloa brizantha cv. Xaraés seeds. African Journal of Agriculture Research, v.13, n.1, p.2804-2807, 2018. http://www.alice.cnptia.embrapa.br/alice/handle/ doc/1102365

PINHEIRO, G.G.; ZANOTTI, R.F.; PAIVA, C.E.C.; LOPES, J.C.; GAI, Z.T. Efeito do estresse salino em sementes e plântulas de feijão guandu. Enciclopédia Biosfera, v.9, n.16, p.901-912, 2013. http://www.conhecer.org.br/enciclop/2013a/agrarias/Efeito\%20do\%20 estresse\%20salino.pdf

PIRES, R.M.D.O.; SOUZA, G.A.D.; CARDOSO, A.Á.; DIAS, D.C.F.S.; BORGES, E.E.L. Action of nitric oxide in sesame seeds (Sesamum indicum L.) submitted to stress by cadmium. Journal of Seed Science, v.38, n.1, p.22-29, 2016. http://dx.doi.org/10.1590/2317$1545 v 38 n 1154824$

RIBEIRO, E.C.G.; REIS, R.D.G.E.; VILAR, C.C.; VILAR, F.C.M. Physiological quality of Urochloa brizantha seeds submitted to priming with calcium salts. Pesquisa Agropecuária Tropical, v.49, 2019. https://doi.org/10.1590/1983-40632019v4955341

SABERALI, S.F.; MORADI, M. Effect of salinity on germination and seedling growth of Trigonella foenum-graecum, Dracocephalum moldavica, Satureja hortensis and Anethum graveolens. Journal of the Saudi Society of Agricultural Sciences, v.18, n.3, p.316-323, 2019. https://doi.org/10.1016/j.jssas.2017.09.004

SIGNORELLI, S.; CONSIDINE, M.J. Nitric oxide enables germination by a four-pronged attack on ABA-induced seed dormancy. Frontiers in Plant Science, v.9, p.296, 2018. https://doi.org/10.3389/fpls.2018.00296

SILVA, A.L.; PINHEIRO, D.T.; SILVA, L.J.; DIAS, D.C.F.S. Effect of cyanide by sodium nitroprusside (SNP) application on germination, antioxidative system and lipid peroxidation of Senna macranthera seeds under saline stress. Journal of Seed Science, v.41, n.1, p.8696, 2019. http://dx.doi.org/10.1590/2317-1545v41n1213725

SILVA, A.L.; DIAS, D.C.F.S.; RIBEIRO, D.M.; SILVA, L.J. Effect of sodium nitroprusside (SNP) on the germination of Senna macranthera seeds (DC. ex Collad.) HS Irwin \& Baneby under salt stress. Journal of Seed Science, v.37, n.4, p.236-243, 2015. http://dx.doi. org/10.1590/2317-1545v37n4153992

VILLELA, F.A.; DONI-FILHO, L.; SEQUEIRA, E.L. Tabela de potencial osmótico em função da concentração de polietilleno glicol 6.000 e da temperatura. Pesquisa Agropecuária Brasileira, v.26, n.11/12, p.1957-1968, 1991. https://www.alice.cnptia.embrapa.br/ handle/doc/106202

WOJTYLA, Ł.; LECHOWSKA, K.; KUBALA, S.; GARNCZARSKA, M. Different modes of hydrogen peroxide action during seed germination. Frontiers in Plant Science, v.7, p.66, 2016. https://doi.org/10.3389/fpls.2016.00066 
YALAMALLE, V.R.; TOMAR, B.S.; JAIN, S.K.; ARORA, A.; KUMAR, A.; MUNSHI, A.D. Spermine induced protection of onion seed vigor and viability during accelerated ageing. Journal of Environmental Biology, v.40, n.5, p.1079-1083, 2019. http://jeb.co.in/journal_ issues/201909_sep19/paper_14.pdf

ZANOTTI, R.F.; LOPES, J.C.; MOTTA, L.B.; FREITAS, A.R.; MENGARDA, L.H.G. Tolerance induction to saline stress in papaya seeds treated with potassium nitrate and sildenafil citrate. Semina: Ciências Agrárias, v.34, p.3669-3674, 2013. https://www.redalyc.org/ articulo.oa?id=445744137047 